\title{
Isolation of Breast Cancer Stem Cell from MDA-MB231 Cell Line Using Vincristine
}

\author{
Aislamiento de Células Madre de Cáncer de Mama \\ de la Línea Celular MDA-MB231 utilizando Vincristina
}

Tara Ghanbari*; Mehri Azadbakht*; Asad Vesi-Raygani** \& Mozafar Khazaei**

GHANBARI, T.; AZADBAKHT, M.; VESI-RAYGANI, A. \& KHAZAEI, M. Isolation of breast cancer stem cell from MDA-MB231 cell line using vincristine. Int. J. Morphol., 34(4):1197-1202, 2016.

SUMMARY: Cancer has been considered as a stem cell disease. Suspension culture combined with anti-cancer drugs has recently been proposed for isolation of cancer stem cells (CSCs). In the current study, Vincristine as an anti-cancer drug combined with suspension culture was used for isolation and purification of CSCs from human breast cancer cell line (MDA-MB231). The cells were treated with different concentrations of vincristine $(0,2,4,6$ and $8 \mathrm{ng} / \mathrm{ml})$. Stem cells were identified with the expression of OCT4, nanog, SOX2 and nucleostemin genes by RT-PCR. Mammosphere forming unit was measured upon suspension culture containing EGF, bFGF, LIF, B27, insulin and BSA. The isolated mammospheres were investigated for CD44 expression. Results showed that $4 \mathrm{ng} / \mathrm{ml}$ of vincristine for 72 hours could be utilized as the best and most reliable dose which eliminates around $80 \%$ of non-cancer stem cells with no destructive effect on CSCs' viability (P> 0.05). RT-PCR demonstrated that drug treated cells expressed OCT4, nanog, SOX2 and nucleostemin. Mammosphere formation unit of cells pretreated with vincristine was significantly higher than unpretreated ones $(\mathrm{P}>0.05)$. Immunofluorescence staining for CD44 depicted high expression of CSC marker among the isolated mammospheres. Vincristine combined with suspension culture can be considered as an appropriate method to isolate CSC.

KEY WORDS: Cancer stem cell; Vincristine; Suspension culture; MDA-MB231.

\section{INTRODUCTION}

Breast cancer remains a leading cause of mortality in women, despite numerous progress in its diagnosis and clinical treatment (Jemal et al., 2006). In the past decades, evidence has emerged the hypothesis that the tumorigenic process is sustained by a small population of cancer cells that posses stem-like characteristics and named cancer stem cells (CSCs). The CSCs are characterized by their ability to undergo self-renewal, a process that leads to tumorigenesis and contributes to tumor cellular heterogeneity (Reya et al., 2001; Clarke et al., 2006; Charafe-Jauffret et al., 2009).

CSC populations have been identified in variety of malignancies, ranging from hematopoietic to several solid tumors including breast cancer tumors (Singh et al., 2004; Bapat et al., 2005; Fang et al., 2005; Collins et al., 2005; Prince et al., 2007; O'Brien et al., 2007; Ricci-Vitiani et al., 2007). Cell surface marker expression, fluorescent dye (Hoechst 33342) exclusion in the side population and tumor sphere formation in the suspension culture are strategies that have been performed to identify Breast Cancer Stem Cells (Al-Hajj et al., 2003). Fluorescence-activated cell sorting (FACS) and Magnetic-activated cell sorting (MACS) are the most common methods for cancer stem cell isolation. However, low viability of isolated cells and high expenses of sorting have decreased its efficacy (Cammareri et al., 2008; Marsden et al., 2009).

Cancer researchers have recently examined suspension culture this procedure has been successfully utilized to form breast cancer stem cell colonies in nonadherent culture condition and to measure their self-renewal and differentiation abilities (Dontu et al., 2003; Ponti et al., 2005; Farnie et al., 2007; Liu et al., 2007). Meanwhile, Yu et al. (2008) reported high efficacy of suspension culture method for isolation of CSC from human glioblastoma cell line (U87).

\footnotetext{
* Department of Biology, Faculty of Basic Sciences, Razi University, Kermanshah, Iran.

${ }^{* *}$ Fertility and Infertility Research Center, Kermanshah University of Medical Sciences, Kermanshah, Iran.
} 
According to Li et al. (2007) hypothesis, chemotherapeutic agents may have the advantage to destroy most dividing cells and retain breast cancer stem cells. So, in recent years suspension culture combined with anti-cancer drugs including vincristine, epirubicin, cisplatin and caffeine has provided an effective tool to isolate, culture and purify CSCs (Yu et al.; Lou et al., 2010). The aimed of present study was to isolate CSCs from a human breast cancer cell line (MDA-MB231) using suspension culture and Vincristine.

\section{MATERIAL AND METHOD}

Cell culture. Human breast cancer cell line (MDAMB231) was purchased from NCBI (National Cell Bank of Iran) and maintained in RPMI-1640 medium with 10 $\%$ fetal bovine serum (FBS) at $37^{\circ} \mathrm{C}$ and $5 \% \mathrm{CO}_{2}$.

Drug treatment. MDA-MB231 cells were plated at a density of $2 \times 10^{4}$ cells/well in 24 -well cell culture plates and treated with different concentrations $(0,2,4,6$ and 8 $\mathrm{ng} / \mathrm{ml}$ ) of vincristine (Richter; Hungry). Cell viability was assessed at different time points $(24,48$ and $72 \mathrm{~h}$ ) by trypan blue dye exclusion and MTT assay (cell proliferation kit, Roche, Denmark, cat\# 1648809). Following the manufacture's protocol, the cells labeled with MTT (3-[4, 5-dimethylthiazol- 2-yl]-2, 5-diphenyl tetrazolium bromide) reagent and were treated for 4 hours at $37^{\circ} \mathrm{C}$. Solubilization solution ( $10 \%$ SDS in $0.01 \mathrm{M}$ $\mathrm{HCl}$ ) was added to cells followed by overnight incubation at $37^{\circ} \mathrm{C}$. Finally, absorbance at $570 \mathrm{~nm}$ was measured using photometer reader (Jenway spectrophotometer).

Suspension culture and mammosphere formation assay. The same density $\left(5 \times 10^{3}\right.$ cells/well $)$ of both drugtreated $(4 \mathrm{ng} / \mathrm{ml}, 72 \mathrm{~h})$ and non-treated cells were plated in 6-well culture plates which had previously been coated with $1.2 \%$ poly 2 - hydroxyethylmethacrylate (Sigmaaldrich, MI,USA). The drug-treated cells chosen for suspension culture which remained attached to the substrate and were alive. The culture medium used for sustaining stem-ness, known as cancer stem cell medium (CSC medium), was RPMI-1640 containing $20 \mathrm{ng} / \mathrm{ml}$ epidermal growth factor (EGF), $10 \mathrm{ng} / \mathrm{ml}$ basic fibroblast growth factor (bFGF), $4 \mu \mathrm{g} / \mathrm{ml}$ insulin, $5 \mu \mathrm{g} / \mathrm{ml}$ hydrocortisone, $10 \mathrm{ng} / \mathrm{ml}$ leukemia inhibitory factor (LIF), $0.5 \%$ bovine serum albumin (Invitrogen ${ }^{\mathrm{TM}}$, CA. USA) and B27 supplement. After seven days of culture, the percentage of mammosphere forming unit (MFU) was calculated using a previously proposed formula (Harrison et al., 2010).
Immunofluorescent staining. Cells were fixed in $4 \%$ paraformaldehyde $(\mathrm{PH}=7.4)$ and were blocked with normal goat serum $(10 \%)$. The primary antibody, rat anti-human CD44 (Santa Cruz Biotechnology, Inc. Santa Cruz, CA. USA), was added and was incubated overnight at $4{ }^{\circ} \mathrm{C}$. After washing 3 times with PBS, the goat anti-rat IgG secondary antibody conjugated with FITC (Santa Cruz Biotechnology, Inc. Santa Cruz, CA. USA) was added and was incubated at room temperature for $1 \mathrm{~h}$. the cells were then washed 3 times with PBS and the images were captured using fluorescent microscope (Nikon- Eclipse TS100-F).

Design of experiment. There were two sets of experiments: First, determination of optimum dose of vincristine which eliminates as much non-CSC as possible without destructive effect on CSCs viability. Both MTT assay and trypan blue staining were conducted for CSCs viability. Second, for identification, isolation and characterization of breast CSCs, self-renewal gene (OCT4, nanog, nucleostemin and SOX2) expression was investigated in drug-resistant cells by RTPCR. Then, mammosphere formation abilities of suspension cultures of both drug-treated and non-treated cells were compared. Finally, mammospheres were characterized using immunofluorescence staining to investigate CSC marker expression.

Statistical analysis. Data were shown as mean \pm standard error and were analyzed using one-way analysis of variance (ANOVA) followed by Tukey test to determine the optimum dose of vincristine. Also, t-test was used to compare the percentage of mammosphere formation units between drugtreated and non-treated cells. Statistical analysis was performed using SPSS 16 for Windows and P values less than 0.05 were considered significant.

\section{RESULTS}

Base on the results shown in Fig. $1 \mathrm{~A}, 4 \mathrm{ng} / \mathrm{ml}$ vincristine for 72 hours can eliminate approximately $80 \%$ of non-resistant MDA-MB231 cells to vincristine. Drug resistant ability could be considered as the first step for purification of CSC from MDA-MB231 cell line. Following 24 hour treatment, the highest absorption (0.74) in MTT assay was observed for control group while the lowest absorption (0.5) was seen at $8 \mathrm{ng} / \mathrm{ml}$ vincristine. Also, the absorption decreased among higher doses after 48 hours (Fig. 1B).

Results demonstrated that cells pretreated with vincristine have much higher ability to form mature mammospheres after seven days of suspension culture with CSC medium (Figs. 2A, B). The percentage of MFU was 

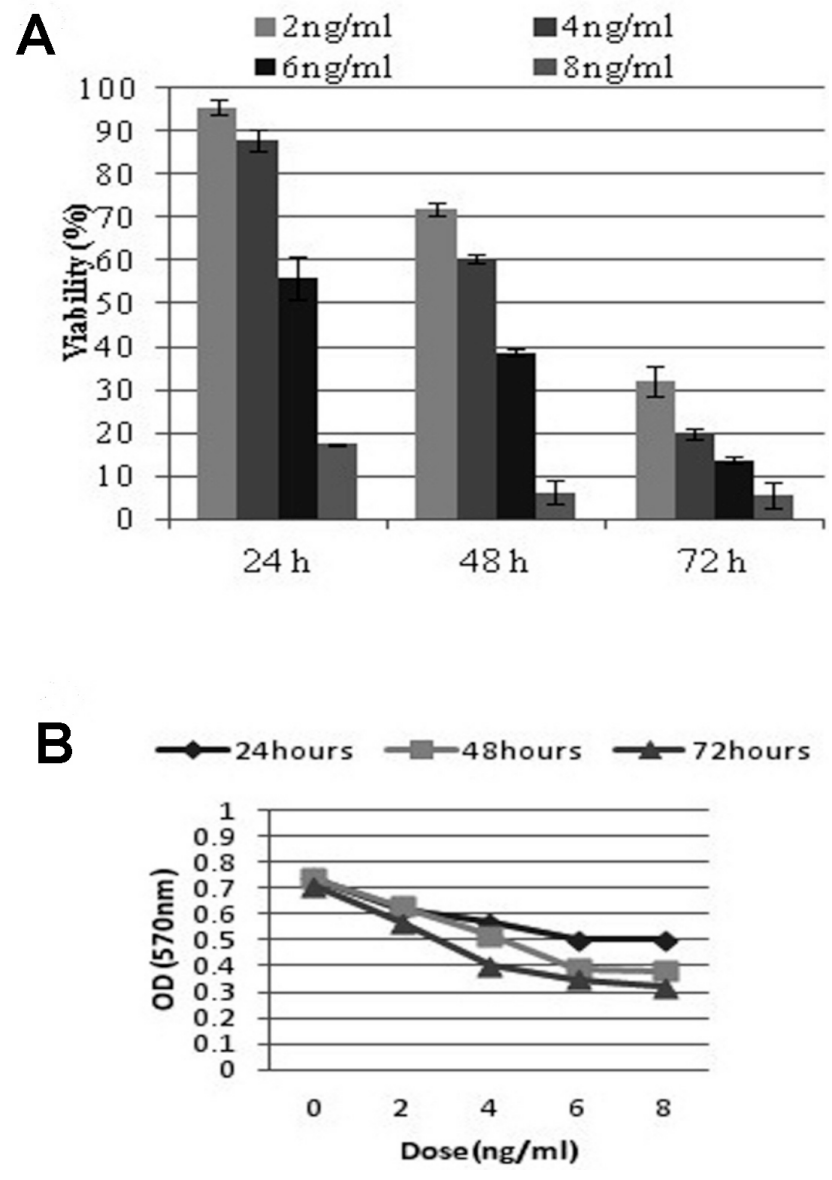

Fig. 1. Both trypan blue dye exclusion (A) and MTT assay (B) demonstrated significant decrease in viability of cells treated with high doses ( 6 and $8 \mathrm{ng}$ ) of vincristine in comparison with low ones (2 and $4 \mathrm{ng})(\mathrm{P}<0.05)$.

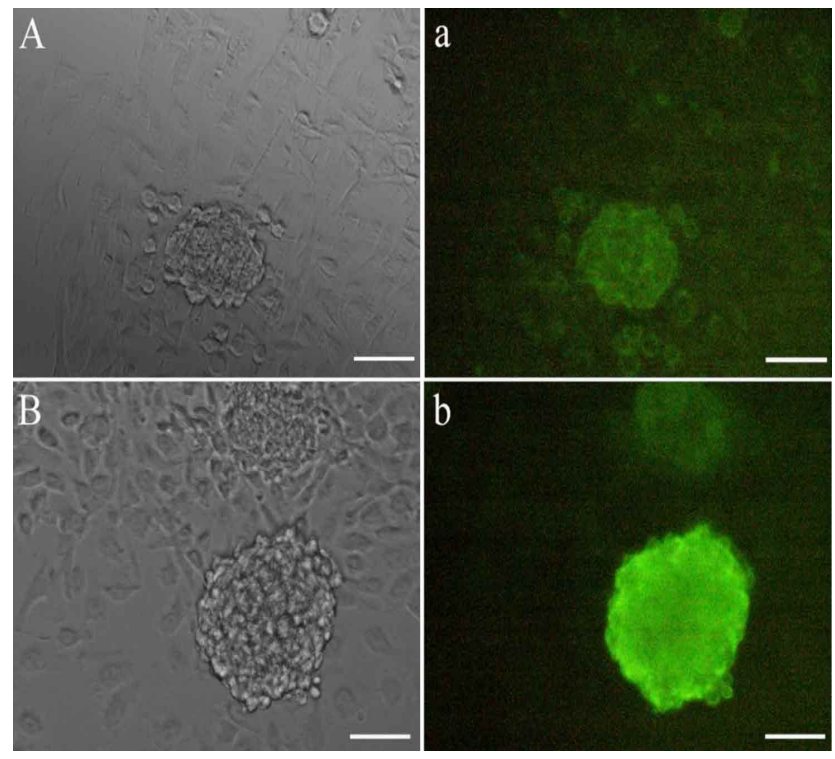

$3.335 \%$ in drug-treated cells in comparison with 0.415 in non-drug treated cells. Also, immunofluorescent staining against CD44 antigen (breast CSC marker) proved that the isolated mammospheres can be considered as a purified CSC population (Fig. 4).

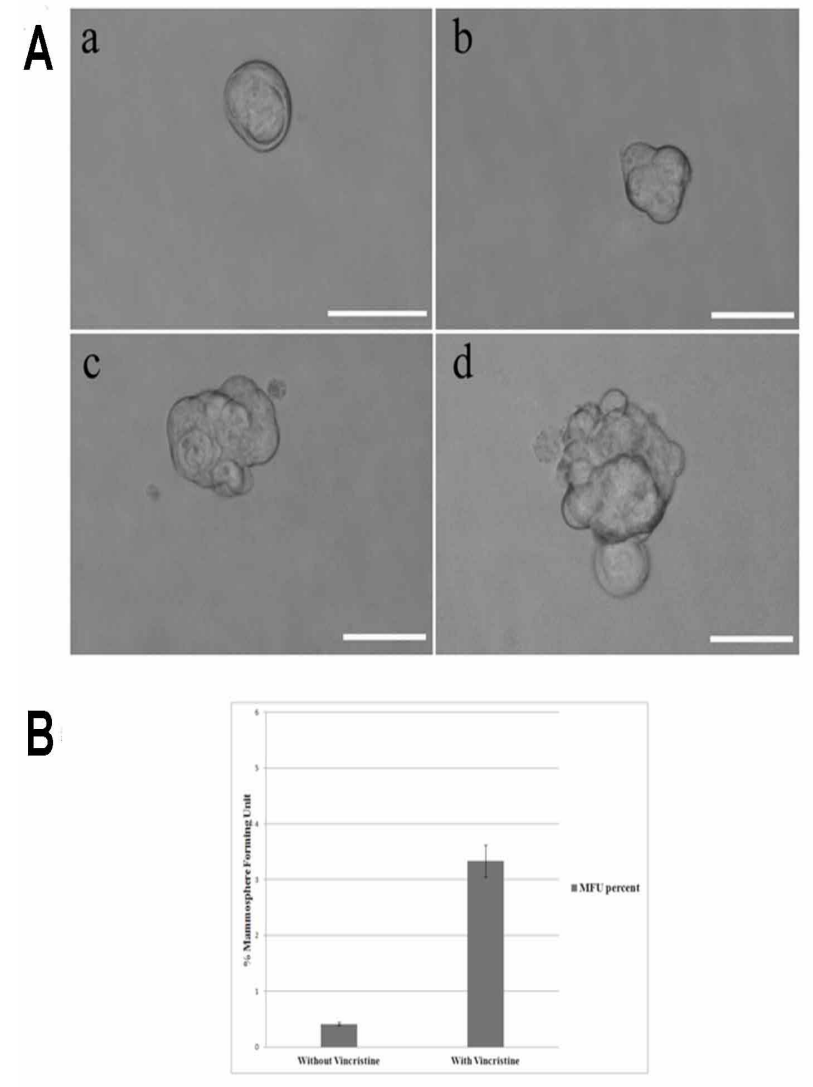

Fig. 2 A. Mammosphere which from a single-cell was formed after cultured in suspension culture condition after 7 days (x 200). a; one day after plating, b, c; 3 and 5 days after plating, d; 7days after plating. B; Results of MFU assay displayed remarkable increase in percentage of MFU among cells pretreated with vincristine $(3.3 \%)$ in comparison with those not treated $(0.4 \%)$, $(\mathrm{P}<0.05)$.

Fig. 4. Expression of CD44 in mammosphere after cell suspension culture. A, B; phase contrast microscopic photo of mammosphere.

a, b; immunofluorescence photo that shows CD44 positive cells. 


\section{DISCUSSION}

The current study indicated that vincristine, an anticancer drug, combined with suspension culture could be considered as a novel and efficient method to isolate CSCs from human breast cancer cell line (MDA-MB231). This isolation was demonstrated based on MFU ability, CSC gene and surface marker expression of drug-treated cell. Also, suspension culture of both drug-treated and nontreated cells was performed to investigate the ability of isolated cells to form mammospheres as one of the most important distinguishing factors that has recently been used for CSCs identification.

The first evidence for isolation tumor-initiating cell using suspension culture back to 2005 (Ponti et al., 2005). The chemotherapy agents may be taken advantage to destroy most dividing cells and retain Breast CSCs. So, suspension culture combined with anti-cancer drugs including epirubicin, cisplatin and caffeine has provided an effective means for isolating, culture and purifying CSCs in recent years. Vincristine has been used in different cell lines (Yu et al.; Lou et al.). In our study, we used vincristine because the cellular mechanism inhibits microtubule polymerization and induces apoptosis (Wang et al., 2003).

It is a critical issue to determine the optimal concentration of vincristine. Certain criteria are required to comply with the requirements of eradicating the vast majority of dividing cells and retaining the minimum number of dormant cells. Because stem cells are more drug-resistant than non-stem cells, in sorting theory, stem cells can separate from non-stem cells among the cancerous population ( $\mathrm{Li}$ et al.). In our experiment, we used $4 \mathrm{ng} / \mathrm{ml}$ drug concentration to eradicate about 80 percent of cell population as other same studies (Singh et al., 2010). Our results of MTT assay illustrated vincristine could be used for elimination of drug-sensitive cancer cells without significant effect on viability and proliferation rate of CSCs.

Generation of tumor sphere is a useful tool to select a CSC population (Ponti et al., 2005). In our experiments, we observed mammosphere formation in serum-free suspension culture in CSCs medium including; EGF, bFGF, Insulin, LIF, B27, Hydrocortisone and BSA. Furthermore, we noticed that vincristine can increase mammosphere formation during suspension culture and this is the same as the results of Yu et al.

We showed that drug-resistant cells express key genes of stem cells: nanog, nucleostemin, OCT4 and
SOX2. Embryonic stem cells (ESCs) are derived from the inner cell mass of blastocyst and proliferate indefinitely while maintaining pluripotency (Smith, 2001). Sox family transcription factors play an essential role in cell differentiation, development and sex determination. SOX2 was previously thought to be the sole Sox protein expressed in ES cells. SOX2 with OCT4 maintain ESCs self-renewal. Nanog is a recently identified divergent homeoprotein that can maintain self-renewal in ESCs. Nucleostemin plays an important role in proliferation and self-renewal of CSC and is also associated with self-renewal ability and maintenance of pluripotency in ESCs (Kafienah et al., 2006; Lacina et al., 2006). These data provide compelling evidence of the presence of side-populations with stemlike properties in breast cancer cell line (MDA-MB231).

We investigated CSCs with expression of selfrenewal genes OCT4, nanog, nucleostemin and SOX2 in drug-resistant cells. Rodda et al. (2005) and Avery et al. (2006) showed the expression of OCT4, nanog and SOX2 in ESCs. Also, Ferberg (2007) indicated expression of these genes in embryonic carcinoma. OCT4 and SOX2 expression in prostate, bladder, brain and lung were reported by Schoenhals et al. (2009). Expression of nucleostemin gene in embryonic and adult stem cells has been confirmed previously (Lacina et al.).

Breast CSCs have been identified as CD44+ and CD24- subpopulations of breast cancer and by exhibition of stem cell features such as self-renewal, differentiation along various mammary epithelial lineages and ability to generate stem cell sphere colonies (Al-Hajj et al.; Ponti et al., 2006). We showed that mammospheres were positive for CD44 breast CSCs marker. This is in line with the previous results which showed tumor sphere can express stem cell markers (Marsden et al.; Lou et al.).

In conclusion, our results indicated that, culture establishment is a simple and accessible method for isolation of CSCs. As a functional sorting method, culture establishment combined with anti-cancer regimens provides a novel approach to enrich and purify CSCs. Combination of pre-selected CSCs and suspension culture in CSC medium could be useful for efficient isolation of CSC from cancer cell lines like MDA-MB231. The possibility of in vitro isolating and propagating CSCs will allow further investigations of selectively activated signaling transduction pathways in the population of CSCs to better understand the mechanisms underlying their survival strategy and to define novel approaches in anti-tumor therapy.

ACKNOWLEDGMENTS. This work was originated from M.Sc. thesis. There is no conflict of interest in this study. 
GHANBARI, T.; AZADBAKHT, M.; VESI-RAYGANI, A. \& KHAZAEI, M. Aislamiento de células madre de cáncer de mama de la línea celular MDA-MB231 utilizando vincristina. Int. J. Morphol., 34(4):1197-1202, 2016.

RESUMEN: El cáncer ha sido considerado como una enfermedad de células madre. Recientemente se ha propuesto cultivo en suspensión en combinación con medicamentos contra el cáncer para aislamiento de las células madre del cáncer (CMC). En este estudio se utilizó la vincristina como fármaco anticanceroso combinado con cultivo en suspensión para el aislamiento y purificación de las células madre cancerosas, de la línea celular de cáncer de mama humano (MDA-MB231). Las células se trataron con diferentes concentraciones de vincristina $(0,2,4,6$ y $8 \mathrm{ng} / \mathrm{ml})$. Las células madre se identificaron mediante la expresión de los genes OCT4, Nanog, SOX2 y nucleostemin por RT-PCR. La unidad de formación mammosphere se midió a través de cultivo en suspensión que contenía EGF, bFGF, LIF, B27, insulina y BSA. Los mammospheres aislados fueron estudiados para la expresión de CD44. Los resultados mostraron que 4 ng/ $\mathrm{ml}$ de vincristina durante 72 horas podrían ser utilizados como la mejor y más fiable dosis que permite eliminar alrededor del $80 \%$ de las células madre no cancerosas, sin causar un efecto destructivo sobre la viabilidad de las CMC (P> 0,05). La RT-PCR mostró que en las células tratadas con él fármaco hubo expresión de los genes OCT4, Nanog, SOX2 y nucleostemin. La unidad de formación de las células pretratadas con vincristina fue significativamente más alta que las unidades sin tratamiento previo (P>0,05). La inmunofluorescencia para CD44 muestró una alta expresión del marcador de CMC entre mammospheres aisladas. La vincristina en combinación con el cultivo en suspensión puede ser considerado como un método apropiado para aislar CMC.

PALABRAS CLAVE: Células madre cancerosas; Vincristina; Cultivo en suspensión; MDA-MB231.

\section{REFERENCES}

Al-Hajj, M.; Wicha, M. S.; Benito-Hernandez, A.; Morrison, S. J. \& Clarke, M. F. Prospective identification of tumorigenic breast cancer cells. Proc. Natl. Acad. Sci. U. S. A., 100(7):3983-8, 2003.

Avery, S.; Inniss, K. \& Moore, H. The regulation of self-renewal in human embryonic stem cells. Stem Cells Dev., 15(5):729-40, 2006.

Bapat, S. A.; Mali, A. M.; Koppikar, C. B. \& Kurrey, N. K. Stem and progenitor-like cells contribute to the aggressive behavior of human epithelial ovarian cancer. Cancer Res., 65(8):3025-9, 2005 .

Cammareri, P.; Lombardo, Y.; Francipane, M. G.; Bonventre. S.; Todaro, M. \& Stassi, G. Isolation and culture of colon cancer stem cells. Methods Cell Biol., 86:311-24, 2008.

Charafe-Jauffret, E.; Ginestier, C.; Iovino, F.; Wicinski, J.; Cervera, N.; Finetti, P.; Hur, M. H.; Diebel, M. E.; Monville, F.; Dutcher, J.; Brown, M.; Viens, P.; Xerri, L.; Bertucci, F.; Stassi, G.; Dontu, G.; Birnbaum, D. \& Wicha, M. S. Breast cancer cell lines contain functional cancer stem cells with metastatic capacity and a distinct molecular signature. Cancer Res., 69(4):1302-13, 2009.

Clarke, M. F.; Dick, J. E.; Dirks, P. B.; Eaves, C. J.; Jamieson, C. H.; Jones, D. L.; Visvader, J.; Weissman, I. L. \& Wahl, G. M. Cancer stem cells-perspectives on current status and future directions: AACR Workshop on cancer stem cells. Cancer Res., 66(19):9339-44, 2006.

Collins, A. T.; Berry, P. A.; Hyde, C.; Stower, M. J. \& Maitland, N. J. Prospective identification of tumorigenic prostate cancer stem cells. Cancer Res., 65(23):10946-51, 2005.
Dontu, G.; Abdallah, W. M.; Foley, J. M.; Jackson, K. W.; Clarke, M. F.; Kawamura, M. J. \& Wicha, M. S. In vitro propagation and transcriptional profiling of human mammary stem/progenitor cells. Genes Dev., 17(10):1253-70, 2003.

Fang, D.; Nguyen, T. K.; Leishear, K.; Finko, R.; Kulp, A. N.; Hotz, S.; Van Belle, P. A.; Xu, X.; Elder, D. E. \& Herlyn, M. A tumorigenic subpopulation with stem cell properties in melanomas. Cancer Res., 65(20):9328-37, 2005.

Farnie, G.; Clarke, R. B.; Spence, K.; Pinnock, N.; Brennan, K.; Anderson, N. G. \& Bundred, N. J. Novel cell culture technique for primary ductal carcinoma in situ: role of Notch and epidermal growth factor receptor signaling pathways. J. Natl. Cancer Inst., 99(8):616-27, 2007.

Harrison, H.; Farnie, G.; Howell, S. J.; Rock, R. E.; Stylianou, S.; Brennan, K. R.; Bundred, N. J. \& Clarke, R. B. Regulation of breast cancer stem cell activity by signaling through the Notch4 receptor. Cancer Res., 70(2):709-18, 2010.

Jemal, A.; Siegel, R.; Ward, E.; Murray, T.; Xu, J.; Smigal, C. \& Thun, M. J. Cancer statistics, 2006. CA Cancer J. Clin., 56(2):106-30, 2006.

Kafienah, W.; Mistry, S.; Williams, C. \& Hollander, A. P. Nucleostemin is a marker of proliferating stromal stem cells in adult human bone marrow. Stem Cells, 24(4):1113-20, 2006.

Lacina, L.; Smetana, K. Jr.; Dvoránková, B.; Stork, J.; Plzáková, Z. \& Gabius, H. J. Immunocyto- and histochemical profiling of nucleostemin expression: marker of epidermal stem cells? $J$. Dermatol. Sci., 44(2):73-80, 2006. 
Li, H. Z.; Yi, T. B. \& Wu, Z. Y. Suspension culture combined with anticancer regimens for screening breast cancer stem cells. Med. Hypotheses, 68(5):988-90, 2007.

Liu, J. C.; Deng, T.; Lehal, R. S.; Kim, J. \& Zacksenhaus, E. Identification of tumorsphere- and tumor-initiating cells in HER2/Neu-induced mammary tumors. Cancer Res., 67(18):8671-81, 2007.

Lou, N.; Wang, Y.; Sun, D.; Zhao, J.; Wang, Y. \& Gao, Z. Isolation of stem-like cells from human MG-63 osteosarcoma cells using limiting dilution in combination with vincristine selection. Indian J. Biochem. Biophys., 47(6):340-7, 2010.

Marsden, C. G.; Wright, M. J.; Pochampally, R. \& Rowan, B. G. Breast tumor-initiating cells isolated from patient core biopsies for study of hormone action. Methods Mol. Biol., 590:363-75, 2009.

O'Brien, C. A.; Pollett, A.; Gallinger, S. \& Dick, J. E. A human colon cancer cell capable of initiating tumour growth in immunodeficient mice. Nature, 445(7123):106-10, 2007.

Ponti, D.; Costa, A.; Zaffaroni, N.; Pratesi, G.; Petrangolini, G.; Coradini, D.; Pilotti, S.; Pierotti, M. A. \& Daidone, M. G. Isolation and in vitro propagation of tumorigenic breast cancer cells with stem/progenitor cell properties. Cancer Res., 65(13):5506-11, 2005.

Ponti, D.; Zaffaroni, N.; Capelli, C. \& Daidone, M. G. Breast cancer stem cells: an overview. Eur. J. Cancer, 42(9):1219-24, 2006.

Prince, M. E.; Sivanandan, R.; Kaczorowski, A.; Wolf, G. T.; Kaplan, M. J.; Dalerba, P.; Weissman, I. L.; Clarke, M. F. \& Ailles, L. E. Identification of a subpopulation of cells with cancer stem cell properties in head and neck squamous cell carcinoma. Proc. Natl. Acad. Sci. U. S. A., 104(3):973-8, 2007.

Reya, T.; Morrison, S. J.; Clarke, M. F. \& Weissman, I. L. Stem cells, cancer, and cancer stem cells. Nature, 414(6859):10511, 2001.

Ricci-Vitiani, L.; Lombardi, D. G.; Pilozzi, E.; Biffoni, M.; Todaro, M.; Peschle, C. \& De Maria, R. Identification and expansion of human colon-cancer-initiating cells. Nature, 445(7123):1115,2007

Rodda, D. J.; Chew, J. L.; Lim, L. H.; Loh, Y. H.; Wang, B.; Ng, H. H. \& Robson, P. Transcriptional regulation of nanog by OCT4 and SOX2. J. Biol. Chem., 280(26):24731-7, 2005.

Schoenhals, M.; Kassambara, A.; De Vos, J.; Hose, D.; Moreaux, J. \& Klein, B. Embryonic stem cell markers expression in cancers. Biochem. Biophys. Res. Commun., 383(2):157-62, 2009.

Singh, S. K.; Hawkins, C.; Clarke, I. D.; Squire, J. A.; Bayani, J.; Hide, T.; Henkelman, R. M.; Cusimano, M. D. \& Dirks, P. B. Identification of human brain tumour initiating cells. Nature, 432(7015):396-401, 2004.

1202
Singh, N.; Chakrabarty, S. \& Liu, G. Multidrug resistance of nonadherent cancer cells. Nature Precedings, 2010. Available from: http://hdl.handle.net/10101/npre.2010.4488.1

Smith, A. G. Embryo-derived stem cells: of mice and men. Annu. Rev. Cell. Dev. Biol., 17:435-62, 2001.

Wang, X.; Jin, D. Y.; Wong, H. L.; Feng, H.; Wong, Y. C. \& Tsao, S. W. MAD2-induced sensitization to vincristine is associated with mitotic arrest and Raf/Bcl-2 phosphorylation in nasopharyngeal carcinoma cells. Oncogene, 22(1):109-16, 2003.

Yu, S. C.; Ping, Y. F.; Yi, L.; Zhou, Z. H.; Chen, J. H.; Yao, X. H.; Gao, L.; Wang, J. M. \& Bian, X. W. Isolation and characterization of cancer stem cells from a human glioblastoma cell line U87. Cancer Lett., 265(1):124-34, 2008.

\author{
Correspondence to: \\ Mozafar Khazaei \\ Fertility and Infertility Research Center \\ Kermanshah University of Medical Sciences \\ Kermanshah \\ IRAN
}

Email: mkhazaei1345@yahoo.com

Received: 28-03-2016

Accepted: 19-08-2016 